\title{
ИЗОТОПНЫЙ СОСТАВ НЕФТЕЙ АРЫСКУМСКОГО ПРОГИБА (ЮЖНЫЙ КАЗАХСТАН)
}

\author{
Голышев Станислав Иванович1, \\ golishev@tf-sniiggims.ru
}

\author{
Падалко Наталья Львовна ${ }^{1}$, \\ padalko@tt-sniiggims.ru
}

Мадишева Рима Копбосынкызы²,
rimma_kz@mail.ru

Оздоев Султан Мажитович ozdoyevsultan@mail.ru

Портнов Василий Сергеевич²,
vs_portnov@mail.ru

Исаев Валерий Иванович 4 , isaevvi@tpu.ru

1 Томский филиал Акционерного общества «Сибирский Научно-Исследовательский Институт Геологии, Геофизики и Минерального Сырья», Россия, 634021, г. Томск, пр. Фрунзе, 232.

2 Карагандинский Государственный технический университет, Казахстан, 100027, г. Караганды, пр. Н. Назарбаева, 56.

3 Институт геологических наук имени К.И. Сатпаева, Казахстан, 050010, г. Алматы, ул. Кабанбай батыра, 69/94.

4 Национальный исследовательский Томский политехнический университет, Россия, 634050, г. Томск, пр. Ленина, 30.

Одним из обсуждаемых направлений в современной геологии является нефтегазоносный потенциал более глубоких горизонтов, в том числе фрундамента осадочных бассейнов. Генезис залежей нефрти является предметом острых дискуссий.

Современные геохимические методы исследования вещества в совокупности с приборными возможностями, к которым можно отнести изотопный масс-спектрометр, позволяют различать неффти, генерированные разными нефтематеринскими отложениями.

Важнейшим показателем, идентифицирующим генезис углеводородов по отношению к зонам нефртегазообразования в конкретном разрезе, является изотопный состав углерода. Каждая зона, в свою очередь, характеризуется индивидуальными геохимическими и термодинамическим параметрами, включающими тип и степень преобразованности рассеянного органического вещества, современные геотемпературы и палеотемпературные условия, фазовый состав углеводородов.

Месторождения Арыскумского прогиба Южно-Торгайского нефртегазоносного бассейна (Южный Казахстан) связаны с различными литолого-стратиграфическими комплексами юрско-меловых отложений, девонско-нижнекаменноугольными образованиями квазиплатформенного комплекса и дезинтегрированными выступами фундамента.

В последние годы перспективы Южно-Торгайского прогиба расширяются и связываются с доюрскими отложениями. В этой связи возникает вопрос о природе углеводородных масс и формировании их скоплений в мезозойских и домезозойских образованиях Арыскумского прогиба.

Цель исследования: проведение сравнительного анализа изотопного состава углерода нефтей Арыскумского прогиба из мезозойских, палеозойские отложений, а также из зоны контакта палеозоя с мезозойским осадочным чехлом для решения генетических задач и выяснения особенностей формирования нефтяных месторождений Арыскумского прогиба.

Результаты позволили установить закономерность изменения величины $\delta^{13} \mathrm{C}$ в зависимости от возраста, глубины, территориальной приуроченности месторождений в пределах Арыскумского прогиба и на основании изотопных данных высказать предположение о генезисе мезозойских и домезозойских нефтей.

\section{Ключевые слова:}

Изотоп углерода, генезис, нефть, Арыскумский прогиб, изотопньй анализ.

\section{Введение}

Важнейшим показателем, идентифицирующим генезис углеводородов по отношению к зонам нефтегазообразования в конкретном разрезе, является изотопный состав углерода. Каждая зона, в свою очередь, характеризуется индивидуальными геохимическими и термо- динамическим параметрами, включающими тип и степень преобразованности рассеянного органического вещества, современные геотемпературы и палеотемпературные условия, фазовый состав углеводородов [1-4].

Поскольку два возможных источника углерода нефтей - органическое вещество морского и конти- 
нентального происхождения - заметно отличаются по изотопному составу, это должно было отразиться на изотопном составе нефтей, принадлежащих различным фациям $[5,6]$.

Распределение изотопов углерода в углеводородах в зависимости от их структуры и молекулярного веса отражает наиболее тонкие стороны процесса образования и превращения нефтей. Сходство или различие нефтей в деталях распределения изотопов углерода в соответствующих углеводородных компонентах может служить признаком их генетической однотипности или генетического различия [7-11]. Ниже сошлемся на два примера современного изотопного анализа нефтей.

В Таримском нефтегазоносном бассейне Китая были исследованы пробы на содержание и происхождение изотопного состава углерода палеозойской нефти кембрийско-ордовикских пород. В результате чего выделены два набора исходных пород с различным составом изотопов углерода: порода из нижнего кембрия с более легким составом изотопов углерода и порода среднего и верхнего кембрия с более тяжелым составом изотопов углерода. Получено значение $\delta^{13} \mathrm{C}$ палеозойской нефти, отобранной из вышеуказанных вмещающих пород. Анализируя результаты исследования было установлено, что кембрийские отложения могут быть основным источником генерации углеводородов в Таримском осадочном бассейне [12].

Для выявления генетических типов и источника природного газа в различных антиклиналях сравнивались и систематически сортировались характери- стики газового состава и изотопного состава углерода и водорода в бассейне Джунгар [13].

Для решения генетических задач и выяснения особенностей формирования нефтяных месторождений Арыскумского прогиба (Южный Казахстан) нами впервые был измерен изотопный состав углерода 14 проб нефтей, любезно предоставленных геологами данных месторождений. Для проведения сравнительного анализа были отобраны пробы нефтей из мезозойских, палеозойских отложений, а также из зоны контакта палеозоя с мезозойским осадочным чехлом.

\section{Краткая нефтегеологическая характеристика территории исследований}

Южно-Торгайский осадочный бассейн, согласно «Карте перспектив нефтегазоносности Казахстана» (2002 г.), относится к Восточному нефтегазогеологическому региону [14] и входит в состав Туранской эпигерцинской плиты, где отложения древнее палеозоя образуют фундамент, на котором залегают слои осадочных горных пород, представленных гнейсами, кварц-биотитплагиоклазового состава, близкие протерозойской секции разреза Улытау [15]. По толщине осадочного чехла, особенностям тектонических и литолого-стратиграфических характеристик Южно-Торгайский осадочный бассейн относится к внутриконтинентальному.

Метаморфический фундамент Южно-Торгайского бассейна состоит из трех блоков: Жиланшикский, Мынбулакский и на юге Арыскумский (рис. 1). Впадина состоит из глубоких, линейно-вытянутых грабен-синклиналей, разделенных резкими выступами домезозойского основания.

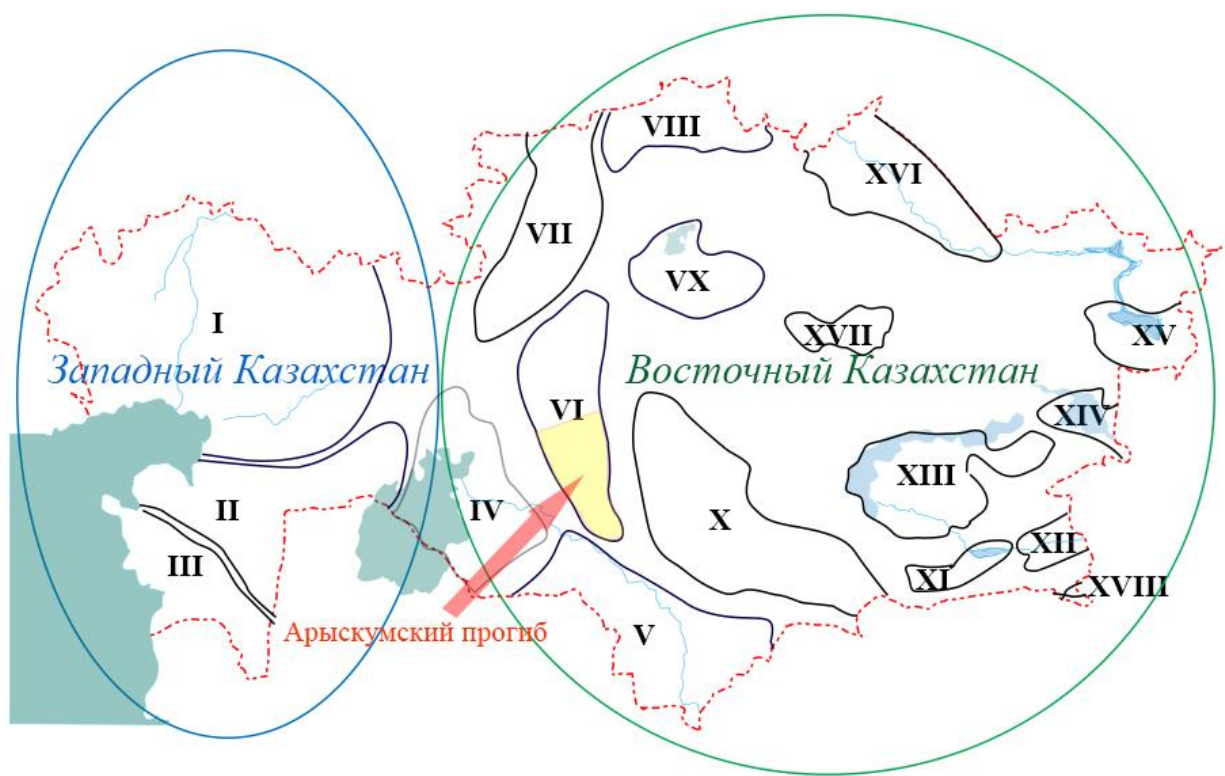

Pис. 1. Схема положения осадочных бассейнов Казахстана: Прикаспийский (I); Устюртско-Бозашинский (II); Мангистауский (III); Аральский (IV); Сырдарьинский (V); Южно-Торгайский (VI); Северо-Торгайский (VII); Северо-Казахстанский (VIII); Тенизский (IX); Шу-Сарысуский (X); Западно-Илийский (XI); Восточно-Илийский (XII); Балхашский (XIII); Алакольский (XIV); Зайсанский (XV), Прииртылиский (XVI); Карагандинский (XVII); Текесско-Каркаринский (XVIII)

Fig. 1. Scheme of location of sedimentary basins of Kazakhstan: Caspian (I); Ustyurt-Bozashinsky (II); Mangistau (III); Aral (IV); Syrdarya (V); South Torgai (VI); Severo-Torgai (VII); North Kazakhstan (VIII); Tenizsky (IX); Shu-Sarysu $(X)$; West Ili (XI); East Ili (XII); Balkhash (XIII); Alakolsky (XIV); Zaysan (XV), Irtysh (XVI); Karaganda (XVII); Tekesko-Karkarinsky (XVIII) 
Все месторождения промышленной значимости приурочены к Арыскумскому прогибу, где в 1984 г. был получен первый фонтан нефти на площади Кумколь из отложений нижнего неокома [16]. Прогиб ограничен на западе Главным Каратауским разломом, а на востоке Западно-Улытауским, имеет северо-западное простирание и характеризуется сложным тектоническим строением. В пределах прогиба выделяются: Арыскумская, Акшабулакская (Бесоба-Теренсайская), Сарыланская, Бозингенская, Даутская и Жинишкекумская грабенсинклинали, образуя систему мезозойских рифтов. Грабены отделяются друг от друга Аксайской, Ащисайской и Табакбулакской горст-антиклиналями.
На тектонической карте Арыскумского прогиба (рис. 2) отмечены месторождения, откуда были отобраны исследованные пробы нефтей.

В строении Южно-Торгайского бассейна принимает участие весь комплекс мезо-кайнозойских отложений, залегающий на домезозойском основании. Г.Ж. Жолтаевым и Т.Х. Парагульговым [17] выделены два структурных этажа - нижний, так называемый промежуточный структурный комплекс, представлен породами верхнего-среднего палеозоя, обладает определенными перспективами нефтегазоносности и верхний платформенный чехол - сложен породами мезозойского и кайнозойского возраста (рис. 3).

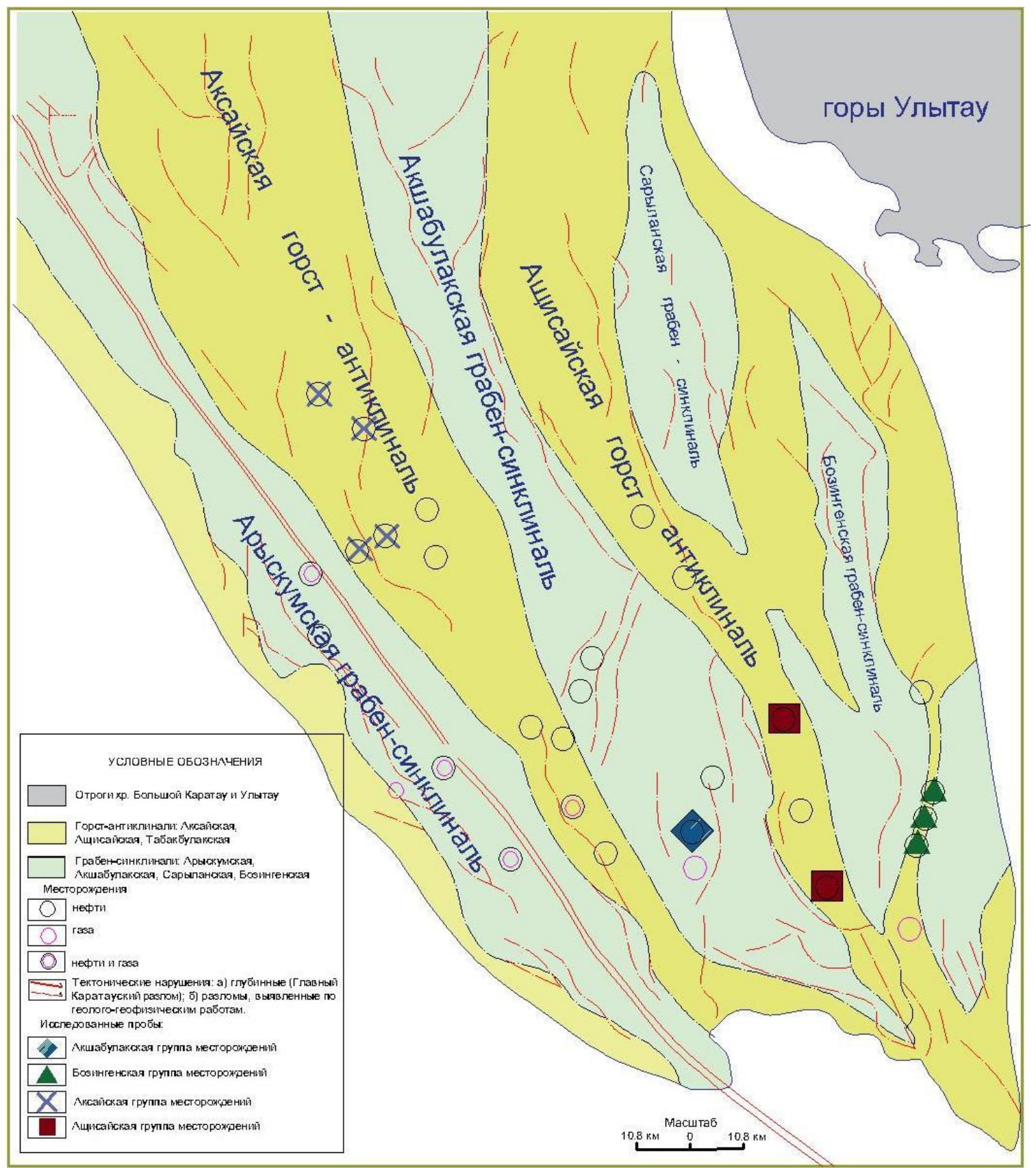

Рис. 2. Схема положения месторождений углеводородов и отбора исследуемых проб нефти на тектонической карте Арыскумского прогиба (по Э.С. Воцалевскому, [18])

Fig. 2. Diagram of location of hydrocarbon deposits and selection of the studied oil samples on the tectonic map of the Aryskum depression (by E.S. Votsalevskiy, [18]) 


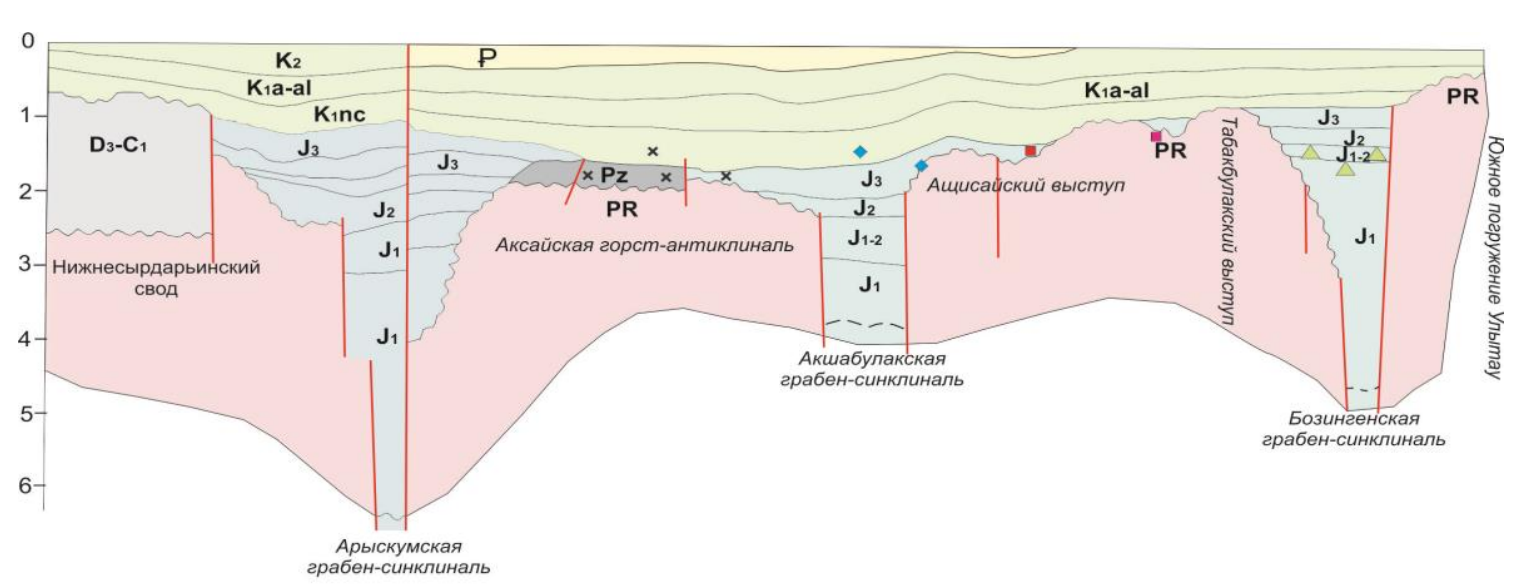

Условные обозначения:

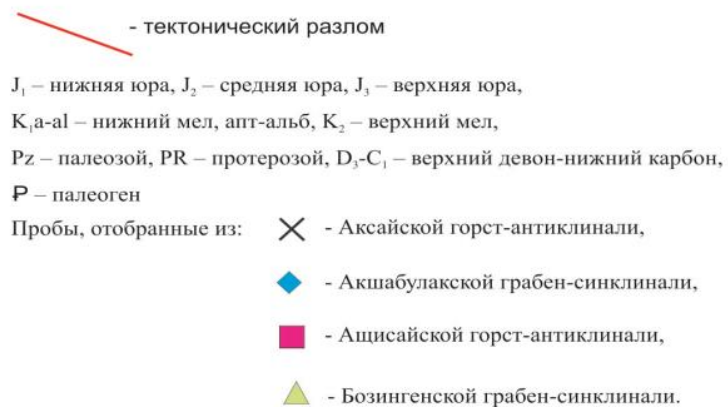

Рис. 3. Стратиграфическое положение исследованных проб нефти на сводном ортогональном геологическом разрезе Арыскумского прогиба

Fig. 3. Stratigraphic position of the studied oil samples in the combined orthogonal geological section of the Aryskum depression

Фундамент бассейна сложен разнообразными глубокометаморфизованными докембрийскими породами [18].

Месторождения Арыскумского прогиба связаны с различными литолого-стратиграфическими комплексами юрско-меловых отложений, девонсконижнекаменноугольными образованиями квазиплатформенного комплекса (КПК) и дезинтегрированными выступами фундамента.

Г.Ж. Жолтаев и Т.Х. Парагульгов стратифицировали нефтегазоносные комплексы на региональные юрский (сингенетический), неокомский (эпигенетический) и зональный коры выветривания пород домезозойского возраста [14].

Юрско-меловые отложения, представляя основную часть осадочного разреза Южного Торгая, по результатам геохимических исследований характеризуются достаточно высокими содержаниями рассеянного органического вещества (РОВ) различного типа, от гумусового до сапропелевого, концентрация которого превышает кларковые значения [18, 19$]$.

Продуктивные горизонты меловых и юрских отложений сложены песчаниками и алевролитами [18].

Нефтегазоносность отложений палеозоя связывают с эрозионными поверхностями с развитыми трещинами, способными аккумулировать УВ, мигрировавшие с мезозойских отложений [20].

Литокомплексы, формирующие юрский и мелпалеогеновый структурные этажи осадочного чехла Южно-Торгайского нефтегазоносного бассейна (НГБ), существенно отличаются друг от друга. Особенностью юрских литокомплексов является формирование их в исключительно внутриконтинентальных условиях, характеризующихся активным тафрогенным тектоническим режимом, обусловившим, в свою очередь, формирование узких линейно-вытянутых грабенов, расширяющихся вверх по разрезу по каждому выполняющему их ритмокомплексу отложений, и разделенных относительно плоскими, устойчивыми выступами фундамента, не испытавшими активного воздымания.

Мел-палеогеновый структурный этаж ЮжноТоргайского НГБ формировался в период длительных прерывисто-пульсационных прогибаний Туранской плиты, сопровождавшихся морскими трансгрессиями.

К началу мелового периода относится формирование постепенно расширяющейся Арыскумской синеклизы, в контуры которой в верхнемеловую и палеогеновую эпохи были вовлечены обрамляющие ее территории в связи со сменой внутриконтинентального режима осадконакопления морским [21].

Большинство нефтей Арыскумского прогиба парафинистые (содержание парафина до 15 \% и более), малосернистые. Анализ физико-химических свойств нефтей исследованных месторождений приведен в табл. 1.

\section{Методика и результаты изотопного анализа}

Изотопные анализы выполнялись в аккредитованной лаборатории изотопных методов (аттестат № RA.RU.517930 от 15 июля 2015 г.) ТФ АО «СНИИГГиМС» на масс-спектрометре DELTA V ADVAN- 
ТА, с учетом химподготовки проб погрешность составляет $\pm 0,5 \%$.

Таблица 1. Физико-химические свойства нефтей Арыскумского прогиба

Table 1. Physicochemical properties of the Aryskum depression oil

\begin{tabular}{|c|c|c|c|c|c|c|}
\hline \multirow[b]{2}{*}{$\begin{array}{c}\text { Группа } \\
\text { Group }\end{array}$} & \multirow[b]{2}{*}{ 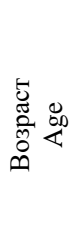 } & \multicolumn{4}{|c|}{$\begin{array}{c}\text { Содержание, \% } \\
\text { Content, \% }\end{array}$} & \multirow{2}{*}{ 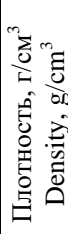 } \\
\hline & & 芑泀 & 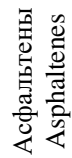 & 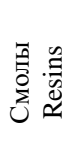 & 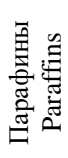 & \\
\hline \multirow{4}{*}{$\begin{array}{l}\text { Аксайская } \\
\text { Aksay }\end{array}$} & $\mathrm{K}_{1} \mathrm{nc}$ & 0,32 & 0,07 & 5,7 & 12,9 & 0,81 \\
\hline & $\mathrm{PZ}$ & 0,28 & 0,05 & 3,6 & 17,3 & 0,78 \\
\hline & $\mathrm{J}_{3}$ & 0,26 & 0,18 & 8,3 & 10,2 & 0,835 \\
\hline & PZ & 0,07 & 0,21 & 2,29 & 6,7 & 0,78 \\
\hline \multirow{2}{*}{$\begin{array}{l}\text { Бозингенская } \\
\text { Bosingen }\end{array}$} & $J_{1-2}$ & 0,08 & 0,2 & 4,2 & 10,1 & 0,82 \\
\hline & $J_{1-2}$ & 0,06 & - & 6,8 & 9,3 & 0,86 \\
\hline \multirow{2}{*}{$\begin{array}{l}\text { Ащисайская } \\
\text { Ashisay }\end{array}$} & $\mathrm{J}-0$ & 0,18 & 0,29 & 25,7 & 16,6 & 0,82 \\
\hline & PR & - & - & - & - & - \\
\hline \multirow{2}{*}{$\begin{array}{l}\text { Акшабулакская } \\
\text { Akshabulak }\end{array}$} & PR & - & - & - & - & - \\
\hline & $\mathrm{K}_{1} \mathrm{nc}$ & 0,23 & - & 8,44 & 14,38 & 0,82 \\
\hline
\end{tabular}

Результаты по углероду приведены к международному стандарту. Стандарт VPDB - это карбонат кальция белемнита позднемелового возраста (формация Пи-Ди, Южная Каролина).

Величина $\delta^{13} \mathrm{C}$ показывает разницу между изотопным составом образца и стандарта:

$$
\delta^{13} \mathrm{C}=\frac{\left({ }^{13} \mathrm{C} /{ }^{12} \mathrm{C}\right)_{\text {обр }}-\left({ }^{13} \mathrm{C} /{ }^{12} \mathrm{C}\right)_{\mathrm{cт}}}{\left({ }^{13} \mathrm{C} /{ }^{12} \mathrm{C}\right)_{\text {ст }}} \cdot 1000, \%
$$

На рис. 2 представлено расположение изученных районов и точки отбора проб.

Месторождения, откуда были отобраны пробы, по территориальной приуроченности можно разделить на 4 группы:

Бозингенская группа месторождений Сарыбулак, Кайнар, Сорколь расположена в южной части Бозингенской грабен-синклинали, продуктивными в данных месторождениях являются средне-нижнеюрские отложения карагансайской и дощанской свит (3 пробы).

Ащисайская группа месторождений Ащисай и Арысское расположена на Ащисайской горстантиклинали. Две пробы были отобраны из протерозоя PR и юрского горизонта J-0.

Аксайская группа месторождений Аксайской горст-антиклинали включает в себя месторождения Кенлык, Карабулак, Юго-Западный Карабулак, откуда были отобраны 7 проб из осадочного чехла (арыскумский горизонт нижнего мела) и из доюрских образований (PZ).

Акшабулакская группа - отобраны 2 пробы из отложений нижнего мела (арыскумский горизонт) и доюрского комплекса (PZ) на месторождении Акшабулак, которое расположено на Акшабулакской грабен-синклинали.

В табл. 2 приведены результаты изотопного состава углерода нефтей перечисленных месторождений.

Таблица 2. Изотопный состав углерода нефтей

Table 2. Isotopic composition of oil carbon

\begin{tabular}{|c|c|c|c|c|c|}
\hline $\begin{array}{l}\text { Группа } \\
\text { Group }\end{array}$ & $\begin{array}{l}\text { Интервал отбора } \\
\text { Sampling interval }\end{array}$ & $\begin{array}{l}\text { Возраст } \\
\text { Age }\end{array}$ & $\begin{array}{l}\text { Литология коллектора } \\
\text { Collector lithology }\end{array}$ & $\begin{array}{c}\text { Пластовая } \\
\text { температура } \\
\text { Reservoir } \\
\text { temperature } \\
{ }^{\circ} \mathrm{C} \\
\end{array}$ & $\begin{array}{c}\delta^{13} \mathrm{C} \\
\% \mathrm{o}\end{array}$ \\
\hline \multirow{2}{*}{$\begin{array}{c}\text { Акшабулакская } \\
\text { Akshabulak }\end{array}$} & $1900,0-1913,0$ & PR & $\begin{array}{l}\text { Песчаники, пески, алевролиты } \\
\text { Sandstones, sands, siltstones } \\
\end{array}$ & 74,6 & $-29,4$ \\
\hline & $1623,0-1633,0$ & $\mathrm{~K}_{1} \mathrm{nc}$ & $\begin{array}{l}\text { Чередование песчаников и конгломератов } \\
\text { Alternation of sandstones and conglomerates }\end{array}$ & 68 & $-30,7$ \\
\hline \multirow{2}{*}{$\begin{array}{l}\text { Ащисайская } \\
\text { Ashisay }\end{array}$} & $1416,0-1432,0$ & PR & $\begin{array}{l}\text { Песчаники, алевролиты, аргиллиты } \\
\text { Sandstones, siltstones, claystones }\end{array}$ & 54,6 & $-29,1$ \\
\hline & $\begin{array}{l}1291,4-1295,0 \\
1300,0-1306,0 \\
1310,8-1313,4 \\
\end{array}$ & $\mathrm{~J}-0$ & $\begin{array}{l}\text { Пестроцветные глины и алевролиты с прослоями слабосце- } \\
\text { ментированного песка } \\
\text { Mottled clays and siltstones with layers of poorly cemented sand }\end{array}$ & 52,3 & $-30,3$ \\
\hline \multirow{3}{*}{$\begin{array}{l}\text { Бозингенская } \\
\text { Bosingen }\end{array}$} & $1703,3-1713,7$ & $\mathbf{J}_{1-2}$ & $\begin{array}{l}\text { Песчаники, алевролиты, аргиллиты } \\
\text { Sandstones, siltstones, claystones }\end{array}$ & 73,7 & $-28,3$ \\
\hline & $1649,0-1662,0$ & $\mathbf{J}_{1-2}$ & $\begin{array}{l}\text { Песчаники с прослоями аргиллитов, гравелитов и сланцев } \\
\text { Sandstones with layers of claystones, gritstones and slate stones }\end{array}$ & 73,2 & $-28,9$ \\
\hline & $905,0-911,0$ & $\mathbf{J}_{1--2}$ & $\begin{array}{l}\text { Песчаники, алевролиты, аргиллиты } \\
\text { Sandstones, siltstones, claystones }\end{array}$ & 44,1 & $-28,0$ \\
\hline \multirow{7}{*}{$\begin{array}{l}\text { Аксайская } \\
\text { Aksay }\end{array}$} & $1468,0-1474,0$ & $\mathrm{~K}_{1} \mathrm{nc}$ & $\begin{array}{l}\text { Аргиллиты, алевролиты, песчаники } \\
\text { Claystones, siltstones, sandstones }\end{array}$ & 62.1 & $-28,7$ \\
\hline & $\begin{array}{l}1884,0-1885,5 \\
1889,5-1892,5\end{array}$ & $\mathrm{~J}_{3}$ & $\begin{array}{l}\text { Песчаники, алевролиты } \\
\text { Sandstones, siltstones }\end{array}$ & 75,2 & $-29,7$ \\
\hline & $\begin{array}{l}1415,0-1417,0 \\
1418,5-1420,5 \\
\end{array}$ & $\mathrm{~K}_{1} \mathrm{nc}$ & \multirow{3}{*}{$\begin{array}{l}\text { Известняки серые, темно-серые с прожилками кальцита } \\
\text { Limestones grey, dark-grey streaked with calcite }\end{array}$} & 57,4 & $-28,7$ \\
\hline & $\begin{array}{l}1291,8-1303,0 \\
1304,0-1313,7\end{array}$ & PZ & & 55,9 & $-28,1$ \\
\hline & $1320,0-1331,5$ & $\mathrm{PZ}$ & & 57,4 & $-27,6$ \\
\hline & $1439,5-1449,5$ & $\mathrm{PZ}$ & $\begin{array}{l}\text { Известняки, песчаники с кальцитом и глинистым материалом } \\
\text { Limestones, sandstones with calcite and clay matter }\end{array}$ & 62.0 & $-28,2$ \\
\hline & $1582,0-1284,0$ & PZ & $\begin{array}{l}\text { Известняки серые, темно-серые с прожилками кальцита } \\
\text { Limestones grey, dark-grey streaked with calcite }\end{array}$ & 57,4 & $-28,3$ \\
\hline
\end{tabular}


Изотопный состав углерода нефтей

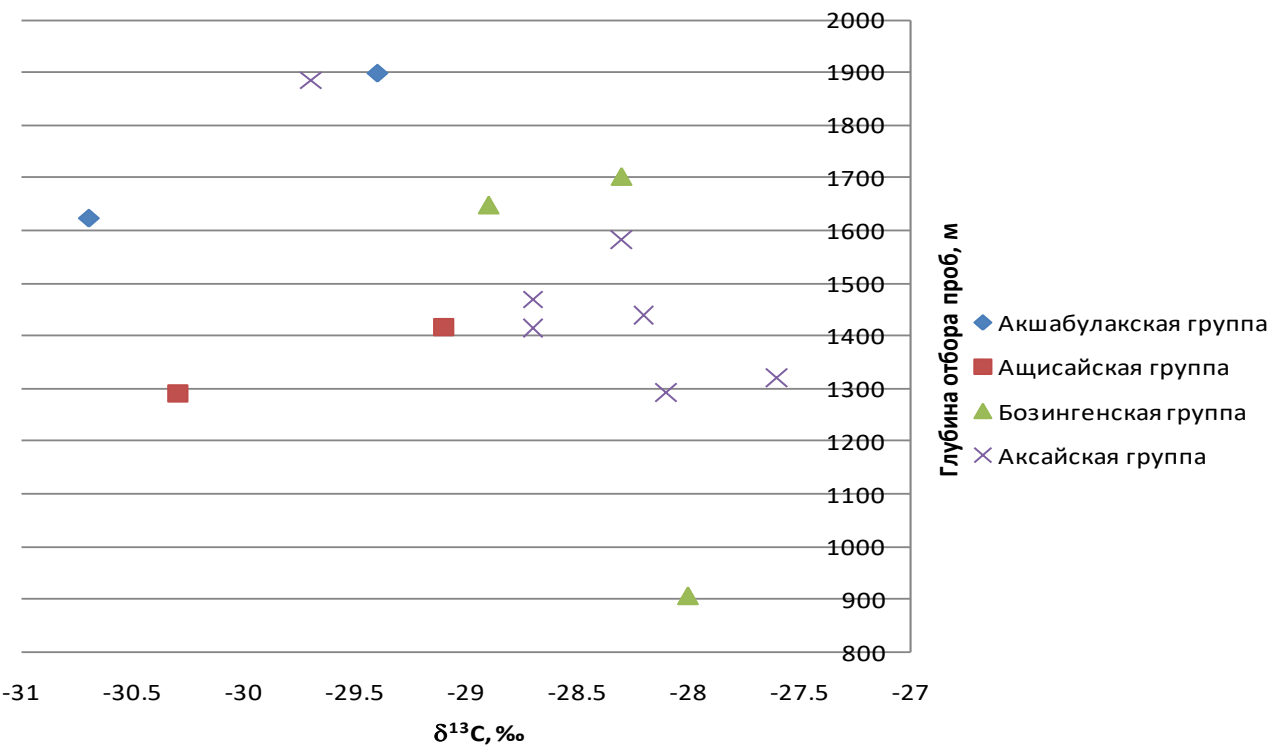

Pис. 4. График распределения изотопа углерода нефтей Арыскумского прогиба

Fig. 4. Graph of carbon isotope distribution in oils from the Aryskum depression

\section{Анализ результатов}

Как видно из таблицы, вариация изотопного состава углерода $\delta^{13} \mathrm{C}$ колеблется в пределах от $-27,6$ до $-30,7 \%$.

На основании полученных результатов построен график распределения изотопного состава углерода от глубины отбора проб (рис. 4).

Нефти Акшабулакской и Ащисайской групп являются наиболее изотопно легкими, с интервалом значений $\delta^{13} \mathrm{C}-29,4$ и $-29,1 \%$ о (отложения протерозоя) и $\delta^{13} \mathrm{C}-30,7$ и $-30,3 \%$ (отложения мела и верхней юры). По изотопным данным нефти мелового и юрского возраста могут быть генетически связаны с органическим веществом (OB) сапропелевого типа (кероген (I, II типа)) собственно одновозрастных отложений Акшабулакской синклинали. Нефти, залегающие в отложениях протерозоя, представляют свою генетическую группу.

Бозингенская группа нефтей имеет узкий диапазон вариаций изотопного состава углерода $\delta^{13} \mathrm{C}:-28,0 \ldots-28,9 \%$, возможно, они образованы из ОВ смешанного типа (гумусово-сапропелевого) юрских отложений Бозингенской грабен-синклинали.

Вариации изотопного состава нефтей в пределах выделенных генетических групп могут быть вызваны различиями компонентного состава, образованного в процессах формирования нефтяных залежей. Дополнительное уточнение генезиса может быть проведено при сопоставлении компонентного и изотопного состава нефтей.

Нефти Аксайской группы по изотопным данным тоже можно разделить на две подгруппы. Первая подгруппа нефтей с изотопно легким составом углерода $\delta^{13} \mathrm{C}-28,7 \ldots-29,7$ \% залегает в более молодых породах мела и верхней юры. Вторая подгруппа представляет более изотопно тяжелые нефти $\delta^{13} \mathrm{C}-27,6 \ldots-28,3 \%$, они расположены в коре выветривания фундамента палеозойского возраста. Изотопно легкие нефти (первая подгруппа) могут быть образованы из одного источника. Вторая подгруппа, залегающая в палеозойском фундаменте, имеет другой источник. Формирование этих залежей, возможно, происходило за счет подтока углеводородов из Арыскумской грабен синклинали.

Зависимость изотопного состава от глубины залегания имеет различную направленность для разных групп нефтей.

Так, для Акшабулакской и Ащисайской групп наблюдается изотопное утяжеление с глубиной расположения залежи.

А для нефтей Аксайской группы прослеживается обратная зависимость: изотопное облегчение с возрастанием глубины расположения залежи.

В целом нефти центральной части Арыскумского прогиба (Акшабулакская, Ащисайская группы нефтей) изотопно легкие $\left(\delta^{13} \mathrm{C}:-29,4 \ldots-30,7 \%\right.$ \%), что может являться результатом их термической преобразованности. Такой узкий диапазон вариаций свидетельствует о генетической связи данных групп.

Стоит отметить, что относительно тяжелый изотопный состав углерода нефтей может быть обусловлен генерацией углеводородов в условиях поздней стадии главной фазы нефтеобразования.

\section{Выводы}

1. Нефти Акшабулакской и Ащисайской групп можно разделить на 2 подгруппы:

- изотопно легких нефтей, залегающая в отложениях мелового и юрского возраста, может быть генетически связана с ОВ сапропелевого типа (кероген I, II типа) собственно одновозрастных отложений Акшабулакской грабенсинклинали; 
- нефти, залегающие в отложениях протерозоя, представляют свою генетическую группу, для уточнения генезиса которой необходимо сопоставление компонентного и изотопного составов.

2. Нефти Аксайской группы можно разделить на две подгруппы:

- изотопно легких нефтей, залегающая в отложениях мелового и юрского возраста, может быть образована ОВ смешанного (сапропелево-гумусового) типа преимущественно морских меловых и верхнеюрских отложений;

- нефти, залегающие в палеозойском фундаменте, возможно, формировались за счет подтока углеводородов из Арыскумской грабенсинклинали.

3. Бозингенская группа нефтей, имеющая узкий диапазон вариаций изотопного состава углерода, возможно, образована из ОВ смешанного типа (гуму-

\section{СПИСОК ЛИТЕРАТУРЫ}

1. Нефть в гранитах фундамента (на примере месторождения Белый Тигр, Вьетнам) / Е.Г. Арешев, В.Е. Гавура, Т.М. Немченко, А.С. Немченко-Ровенская, Б.А. Руденко // Геология, геофизика, разработка нефтяных и газовых месторождений. - 2006. - № 12. - С. 4-13.

2. Differential fluid migration behaviour and tectonic movement in Lower Silurian and Lower Cambrian shale gas systems in China using isotope geochemistry / Wen Zhoua, Qian Caoc Christopher, Xiaod Qiumei, Zhoub Haotian, Zhanga Yeyu Zhangc // Marine and Petroleum Geology. - 2018. - V. 89. - P. 1. - P. 47-57.

3. Characteristics of stable carbon isotopic composition of shale gas / Zhenya Qu, Jianan Sun, Jianting Shi, Zhaowen Zhan, Yanrong Zou, Ping'an Peng // Journal of Natural Gas Geoscience. - 2016. V. 1. - Iss. 2. - P. 147-155.

4. Origin of near-surface hydrocarbon gases bound in northern Barents Sea sediments / Ph. Weniger, M. Blumenberg, K. Berglar, A. Ehrhardt, P. Klitzke, M. Krüger, R. Lutz // Marine and Petroleum Geology. - 2019. - V. 102. - P. 455-476.

5. Галимов Э.М. Геохимия стабильных изотопов. - М.: Недра, 1968. $-226 \mathrm{c}$.

6. Stable isotope reversal and evolution of gas during the hydrous pyrolysis of continental kerogen in source rocks under supercritical conditions / Yuandong Wu, Zhongning Zhang, Lina Sun, Yuanju Li, Mingzheng Zhang, Liming Ji // International Journal of Coal Geology. - 2019. - V. 205. - P. 105-114.

7. Галимов Э.М. Изотопы углерода в нефтегазовой геологии. М.: Недра, 1973. - 384 c.

8. Условия осадконакопления и вторичные изменения пород меловых отложений разрезов скважин в связи с оценкой нефтегазоносности юго-востока ЗСП по данным изотопных исследований / С.И. Голышев, Н.Л. Падалко, Л.В. Смирнов, М.И. Праздничных, Е.В. Черников, П.Ф. Яворов // Химия нефти и газа: Девятая международная конференция. - Томск: Институт Оптики Атмосферы сибирского отделения Российской академии наук, 2015. - С. 128-132.

9. Хант Дж. Геохимия и геология нефти и газа. - М.: Мир, 1982. $-706 \mathrm{c}$.

10. Paradox in bulk and molecular geochemical data and implications for hydrocarbon migration in the inter-salt lacustrine shale oil reservoir, Qianjiang Formation, Jianghan Basin, central China / Xiaoxiao Maab, Maowen Lib, Xiongqi Panga, XueyingWeia, MenhuiQianb, Guoliang Taob, Peng Liub, Qigui Jiangb, Zhiming Lib, Yi Zhaoa, Shiqiang Wuc // International Journal of Coal Geology. - 2019. - V. 209. - P. 72-88.

11. Origin and migration of oil and natural gas in the western part of the Ukrainian Outer Carpathians: geochemical and geological approach / M. Kotarba, D. Więcław, E. Bilkiewicz, N. Radkovets, Y. Koltun, N. Kmiecik, T. Romanowski, A. Kowalski // Marine and Petroleum Geology. - 2019. - V. 103. - P. 596-619. сово-сапропелевого) юрских отложений Бозингенской грабен-синклинали.

Также результаты анализа показали ярко выраженную зависимость изотопного состава нефтей от глубины отбора, а именно, для Акшабулакской и Ащисайской групп наблюдается изотопное утяжеление с глубиной расположения залежи, а для нефтей Аксайской группы прослеживается обратная зависимость: изотопное облегчение с возрастанием глубины расположения залежи. 4. Согласно геологическому разрезу прогиба Акшабулакский грабен и Ащисайский горст осложнены секущими разломами, которые могли служить миграционными каналами для углеводородов. Основываясь на данном факте можно предположить, что изотопно близкие значения углерода нефтей Ащисайской горст-антиклинали свидетельствуют об их генетической связи с нефтями Акшабулакского грабена и имеют один источник генерации из одного органического вещества.

12. Carbon isotopic compositions and origin of Paleozoic crude oil in the platform region of Tarim Basin, NW China / Zhu Xinjian, Chen Jianfa, Wu Jianjun, Wang Yifan, Zhang Baoshou, Zhang Ke, He Liwen // Petrol. Explor. Develop. - 2017. - V. 44. - Iss. 6. P. $1053-1060$

13. Genetic type and source of natural gas in the southern margin of Junggar Basin, NW China / Chen Jianping, Wang Xulong, Ni Yunyan, Xiang Baoli, Liao Fengrong, Liao Jiande, Zhao Changyi // Petrol. Explor. Develop. - 2019. - V. 46. - Iss. 3. - P. 482-495.

14. Аральский бассейн - особенности строения и перспективы нефтегазоносности / У.А. Акчулаков, А.Б. Бигараев, М.А. Куанышев, С.М. Оздоев // Известия Национальной академии наук Республики Казахстан, серия геологии и технических наук. - 2013. - № 5. - С. 48-56.

15. Фишман И.Л. Геодинамические модели Арало-Каспийского региона. - Алматы: Академия минеральных ресурсов Республики Казахстан, 2016. - 156 с.

16. Торгайско-Сырдарьинский регион - эволюция глубинного строения и проблемы минерагении / T.X. Парагульгов, Х.Х. Парагульгов, Е.М. Фазылов, Л.В. Шабалина // Региональная геология, Известия Национальной академии наук Республики Казахстан. - 2013. - № 2. - Р. 8-18.

17. Геология нефти и газа / Г.Ж. Жолтаев, П.Т. Гайковой, Б.М. Абишев, Г. Ермекбаева. - Алматы: Казахский Национальный Технический Университет, 2010. - 193 с.

18. Глубинное строение и минеральные ресурсы Казахстана. Нефть и газ. Т. III / С.Ж. Даукеев, Б.С. Ужкенов, А.А. Абдулин, Х.А. Беспаев, Э.С. Воцалевский, В.Н. Любецкий, А.К. Мазуров, Л.А. Мирошниченко. - Алматы: Республиканское Государственное Предприятие «Информационноаналитический центр геологии и минеральных ресурсов Республики Казахстан», 2002. - 248 с.

19. Ozdoev S.M. Prospects oil-and-gas-bearing sedimentary basins of Kazakhstan // News of the national academy of sciences of the Republic of Kazakhstan, series of geology and technical sciences. - 2012. - V. 1. - № 435. - P. 61-76.

20. Нукенов М.К., Болат Е. Строение и перспективы нефтегазоносности Нижнесырдарьинского свода в зоне сочленения с Южно-Торгайским бассейном // Известия Национальной академии наук Республики Казахстан, Серия геологии и технических наук. -2015 . - № 4. - С. 43-52.

21. Бисенгалиев Д.Л., Темирхасов А.М. Строение и перспективы меловых отложений западной части Южно-Торгайского бассейна по новым сейсморазведочным данным // Известия Национальной академии наук Республики Казахстан, Серия геологии и технических наук. - 2015. - № 4. - С. 33-42.

Поступила 14.11.2019 2. 


\section{Информация об авторах}

Голышев С.И., кандидат физико-математических наук, ведущий научный сотрудник, Томский филиал Акционерного общества «Сибирский Научно-Исследовательский Институт Геологии, Геофизики и Минерального Сырья».

Падалко Н.Л., кандидат химических наук, заведующий лабораторией Томского филиала Акционерного общества «Сибирский Научно-Исследовательский Институт Геологии, Геофизики и Минерального Сырья».

Мадишева P.K., докторант $\mathrm{PhD}$ кафедры геологии и разведки месторождений полезных ископаемых Карагандинского Государственного Технического Университета.

Оздоев C.M., доктор геолого-минералогических наук, профессор, академик Национальной академии наук Республики Казахстан, руководитель лаборатории нефти и газа Института геологических наук имени К.И. Сатпаева.

Портнов В.С., доктор технических наук, профессор кафедры геологии и разведки месторождений полезных ископаемых Карагандинского Государственного Технического Университета.

Исаев В.И., доктор геолого-минералогических наук, профессор отделения геологии Инженерной школы природных ресурсов Национального исследовательского Томского политехнического университета. 
UDC 553.98; 550.4

\title{
ISOTOPIC COMPOSITION OF THE ARYSKUM DEPRESSION OIL (SOUTH KAZAKHSTAN)
}

\author{
Stanislav I. Golyshev 1 , \\ golishev@tf-sniiggims.ru
}

\author{
Nataliya L. Padalko ${ }^{1}$, \\ padalko@tf-sniiggims.ru
}

Rima K. Madisheva², rimma_kz@mail.ru

Sultan M. Ozdoev3, ozdoyevsultan@mail.ru

Vasiliy S. Portnov², vs_portnov@mail.ru

Valery I. Isaev ${ }^{4}$, isaevvi@tpu.ru

1 Tomsk branch of a joint stock company «Siberian Research Institute of Geology, Geophysics and Mineral Raw Materials», 232, Frunze avenue, 634021, Tomsk, Russia.

2 Karaganda State Technical University, 56, N. Nazarbayev avenue, 100027, Karaganda, Kazakhstan.

3 Institute of Geological Sciences n.a. K.I. Satpayev, 69/94, Kabanbai batyr street, Almaty, 050010, Kazakhstan.

${ }^{4}$ National Research Tomsk Polytechnic University, 30, Lenin avenue, Tomsk, 634050, Russia.

One of the areas discussed in modern geology is the oil and gas potential of deep horizons, including the basement of sedimentary basins. The genesis of oil deposits is the subject of heated debate.

Modern geochemical methods for studying a substance, together with the instrument capabilities, which include an isotopic massspectrometer, make it possible to distinguish between oils generated by different oil source deposits.

The most important indicator identifying the genesis of hydrocarbons with respect to oil and gas formation zones in a specific section is the isotopic composition of carbon. Each zone, in its turn, is characterized by individual geochemical and thermodynamic parameters, including the type and degree of conversion of dispersed organic matter, modern geothermal temperatures and paleotemperature conditions, and the phase composition of hydrocarbons.

Deposits of the Aryskum depression of the South Torgai oil and gas basin (South Kazakhstan) are associated with various lithologicalstratigraphic complexes of the Jurassic-Cretaceous deposits, the Devonian-Lower Carboniferous formations of the quasi-platform complex and disintegrated basement ledges.

In recent years, the prospects of the South Torgai basin have expanded and are associated with pre-Jurassic deposits. In this regard, there is the issue of the nature of hydrocarbon masses and formation of their clusters in the Mesozoic and Pre-Mesozoic formations of the Aryskum depression.

The aim of the research is the comparative analysis of the carbon isotopic composition of oils from the Aryskum depression from the Mesozoic, Paleozoic sediments, as well as the ones from the zone of contact of the Paleozoic with the Mesozoic sedimentary cover to solve genetic problems and elucidate the features of the formation of oil fields in the Aryskum depression.

The results made it possible to establish the regularity of the change in the $\delta^{13} \mathrm{C}$ value depending on the age, depth, and territorial confinement of the deposits within the Aryskum depression and, based on isotopic data, make an assumption about the genesis of Mesozoic and Pre-Mesozoic oils.

Key words:

Carbon isotope, genesis, oil, Aryskum deflection, isotope analysis.

\section{REFERENSES}

1. Areshev E.G., Gavura V.E., Nemchenko T.M., NemchenkoRovenskaya A.S., Rudenko B.A. Neft v granitakh fundamenta (na primere mestorozhdeniya Bely Tigr, Vietnam) [Oil in the granites of the foundation (on the example of the White Tiger deposit, Vietnam)]. Geology, geophysics, development of oil and gas fields, 2006, no. 12, pp. 4-13.

2. Wen Zhoua, Qian Caoc Christopher, Xiaod Qiumei, Zhoub Haotian, Zhanga Yeyu Zhangc. Differential fluid migration behaviour and tectonic movement in Lower Silurian and Lower Cambrian shale gas systems in China using isotope geochemistry. Marine and Petroleum Geology, 2018, vol. 89, P. 1, pp. 47-57.

3. Zhenya Qu, Jianan Sun, Jianting Shi, Zhaowen Zhan, Yanrong Zou, Ping'an Peng. Characteristics of stable carbon isotopic composition of shale gas. Journal of Natural Gas Geoscience, 2016, vol. 1, Iss. 2, pp. 147-155.

4. Weniger Ph., Blumenberg M., Berglar K., Ehrhardt A., Klitzke P., Krüger M., Lutz R. Origin of near-surface hydrocarbon gases bound in northern Barents Sea sediments. Marine and Petroleum Geology, 2019, vol 102, pp. 455-476. 
5. Galimov E.M. Geokhimiya stabilnykg izotopov [Geochemistry of stable isotopes]. Moscow, Nedra Publ., 1968. 226 p.

6. Yuandong $\mathrm{Wu}$, Zhongning Zhang, Lina Sun, Yuanju Li, Mingzheng Zhang, Liming Ji. Stable isotope reversal and evolution of gas during the hydrous pyrolysis of continental kerogen in source rocks under supercritical conditions. International Journal of Coal Geology, 2019, vol. 205, pp. 105-114.

7. Galimov E.M. Izotopy ugleroda v neftegazovoy geologii [Carbon isotopes in oil and gas geology]. Moscow, Nedra Publ., 1973. $384 \mathrm{p}$.

8. Golyshev S.I., Padalko N.L. Smirnov L.V., Festive M.I., Chernikov E.V., Yavorov P.F. Usloviya osadkonakopleniya i vtorichnye izmeneniya porod melovykh orlozheny rezervov skvazhin $\mathrm{v}$ svyazi s otsenkoy neftegazonosnosti yugo-vostoka ZSP po dannym izotopnykh issledovany [Sedimentation conditions and secondary changes in the Cretaceous rocks of well sections in relation to assessment of the oil and gas potential of the southeast of the ZSP according to isotope studies]. Devyataya mezhdunarodnaya konferentsiya. Khimiya nefti i gaza [Ninth International Conference. Chemistry of oil and gas]. Tomsk, Institute of optics of the atmosphere of the Siberian branch of the Russian Academy of Sciences, 2015. pp. 128-132.

9. Hunt J. Geokhimiya i geologiya nefri i gaza [Geochemistry and geology of oil and gas]. Moscow, Mir Publ., 1982. 706 p.

10. Xiaoxiao Maab, Maowen Lib, Xiongqi Panga, Xueying Weia, Menhui Qianb, Guoliang Taob, Peng Liub, Qigui Jiangb, Zhiming Lib, Yi Zhaoa, Shiqiang Wuc. Paradox in bulk and molecular geochemical data and implications for hydrocarbon migration in the inter-salt lacustrine shale oil reservoir, Qianjiang Formation, Jianghan Basin, central China. International Journal of Coal Geology, 2019, vol. 209, pp. 72-88.

11. Kotarba M., Wieçaw D., Bilkiewicz E., Radkovets N., Koltun Y., Kmiecik N., Romanowski T., Kowalski A. Origin and migration of oil and natural gas in the western part of the Ukrainian Outer Carpathians: Geochemical and geological approach. Marine and Petroleum Geology, 2019, vol. 103, pp. 596-619.

12. Zhu Xinjian, Chen Jianfa, Wu Jianjun, Wang Yifan, Zhang Baoshou, Zhang Ke, He Liwen. Carbon isotopic compositions and origin of Paleozoic crude oil in the platform region of Tarim Basin, NW China. Petrol. Explor. Develop., 2017, vol. 44 (6), pp. 1053-1060.

13. Chen Jianping, Wang Xulong, Ni Yunyan, Xiang Baoli, Liao Fengrong, Liao Jiande, Zhao Changyi. Genetic type and source of natural gas in the southern margin of Junggar Basin, NW China Petrol. Explor. Develop., 2019, vol. 46 (3), pp. 482-495.
14. Akchulakov U.A., Bigaraev A.B., Kuanyshev M.A., Ozdoev S.M. Aralsky basseyn - osobennosti stroeniya i perspektivy razvitiya [Aral basin - structural features and oil and gas prospects]. Bulletin of the National Academy of Sciences of the Republic of Kazakhstan. Ser. Geol., 2013, no. 5, pp. 48-56.

15. Fishman I.L. Geodinamicheskie modeli Aralo-Kaspiyskogo regiona [Geodynamic models of the Aral-Caspian region]. Almaty, Academy of Mineral Resources of the Republic of Kazakhstan Publ., 2016. $156 \mathrm{p}$

16. Paragulgov T.H., Paragulgov H.H., Fazylov E.M., Shabalin L.V. Torgaysko-Syrdaryinsky region - evolyutsiya glubinnogo stroeniya i problem mineragenii [Torgaysko-Syrdarya region - evolution of the deep structure and problems of mineralogy]. Regional Geology, News of the National Academy of Sciences of the Republic of Kazakhstan, 2013, no. 2, pp. 8-18.

17. Zholtaev G.Zh., Gaykova P.T., Abishev B.M., Ermekbaeva G. Geologiya nefri i gaza [Geology of oil and gas]. Almaty, Kazakh National Technical University Publ., 2010. 193 p.

18. Daukeev S.Zh., Uzhkenov B.S., Abdulin A.A., Bespaev H.A., Votsalevsky E.S., Lyubetskiy V.N., Mazurov A.K., Miroshnichenko L.A. Glubinnoe stroenie i mineralnye resursy Kazakhstana. Neft i gaza. T. III [Deep structure and mineral resources of Kazakhstan. Oil and gas. Vol. III]. Almaty, Republican State Enterprise «Information and Analytical Center of Geology and Mineral Resources of the Republic of Kazakhstan» Publ., 2002. 248 p.

19. Ozdoev S.M. Prospects oil-and-gas-bearing sedimentary basins of Kazakhstan. News of the national academy of sciences of the Republic of Kazakhstan series of geology and technical sciences, 2012, vol. 1, no. 435, pp. 61-76.

20. Nukenov M.K., Bolat E. Stroenie i perspektivy neftegazonosnosti Nizhnesyrdarynskogo svoda $\mathrm{v}$ zone sochleneniya s YuzhnoTorgayskim basseynom [The structure and prospects of oil and gas potential of the Lower Syrdarya arch in the zone of articulation with the South Torgai basin]. News of the National Academy of Sciences of the Republic of Kazakhstan, series of geology and technical sciences, 2015 , no. 4, pp. 43-52.

21. Bisengaliev D.L., Temirkhasov A.M. Stroenie i perspektivy melovykh orlozheny zapadnoy chasti Yuzhno-Torgayskogo basseyna po novym seysmorazvedochnym dannym [The structure and prospects of Cretaceous deposits of the western part of the South Torgai basin according to new seismic data]. News of the National Academy of Sciences of the Republic of Kazakhstan RK, series of Geology and Technical Sciences, 2015, no. 4, pp. 33-42.

Received: 14 November 2019.

\section{Information about the authors}

Stanislav I. Golyshev, Cand. Sc., leading researcher, Tomsk branch of a joint stock company «Siberian Research Institute of Geology, Geophysics and Mineral Raw Materials».

Nataliya L. Padalko, Cand. Sc., head of the Laboratory, Tomsk branch of a joint stock company «Siberian Research Institute of Geology, Geophysics and Mineral Raw Materials».

Rima K. Madisheva, doctoral candidate, Karaganda State Technical University.

Sultan M. Ozdoev, Dr. Sc., professor, Academician of the National Academy of Sciences of the Republic of Kazakhstan, head of the Oil and Gas Laboratory, Institute of Geological Sciences n.a. K.I. Satpayev.

Vasiliy S. Portnov, Dr. Sc., professor, Karaganda State Technical University.

Valery I. Isaev, Dr. Sc., professor, National Research Tomsk Polytechnic University. 